\title{
Max Losting - Bergens-lege og kunstner
}

\author{
På det tidligere Anatomisk institutt kan man snuble over kulturskatter - som blant annet de tegningene \\ av Max Losting som presenteres her.
}

Per Holck

per.holck@medisin.uio.no

Knapt noen norsk medisinsk institusjon gjemmer så mange eldre kulturskatter som det som engang het Anatomisk institutt ved Universitetet i Oslo. Bøker, gjenstander og brev - det er alt sammen vitnesbyrd om den interesse, vidsyn og faglige bredde som de gamle professorene var i besittelse av, og den evne og vilje de hadde til å samle og bevare ting fra fortiden. Hvor spennende er da ikke dette for en gammel emeritus som nå av og til får anledning til å gjennomgå noen saker han har sett liggende, papirer som kanskje allerede lå der da undertegnede tiltrådte som ung stipendiat, og som av seg selv aldri avslørte sitt innhold. Men som nå vekker nysgjerrigheten på nytt.

I en arkivskuff ligger en liten mappe av tilklippet kartong. Den er grå av elde og støv, men innholdet er friskt nok: 20 tegninger eller mer presist: akvareller - av anatomiske strukturer, hver av dem signert «M. Losting». Motivene er muskelpreparater fra de store leddområdene i kroppen: skulder, hånd, hofte, kne og fot. Hvert ark måler ca. $21 \times 18$ $\mathrm{cm}$, og både tegninger og skrift er minutiøst utført. At det har vært en virkelig kunstner som har utført dem, er det ingen tvil om. Han må også ha vært vel bevandret i anatomien. Kanskje var han medisiner?
Og sannelig - her kommer Norges leger oss til hjelp (1). For der finner vi en Max Johan Losting (1841-1911), bylege i Bergen, som ifølge nekrologen (2) var «en fortrinlig tegner». Han bosatte seg for godt i Bergen etter endt studium i 1869, og i fødebyen hadde han flere viktige stillinger, bl.a. innen psykiatri og leprapleie. «Losting var en af de bedst kjendte skikkelser i Bergen, og han holdt af sin by, som bare en bergenser kan gjøre det» (1). Omtanke for de syke må han ha hatt, for han skal ha vært «utrættelig i at tilsé sine patienter, og forstod i sjelden grad at muntre og trøste dem» (2). Men han omtales også som særlig kunst- og historieinteressert, og han var styremedlem i Bergens kunstforening $\mathrm{og} \mathrm{i}$ byens historiske forening.

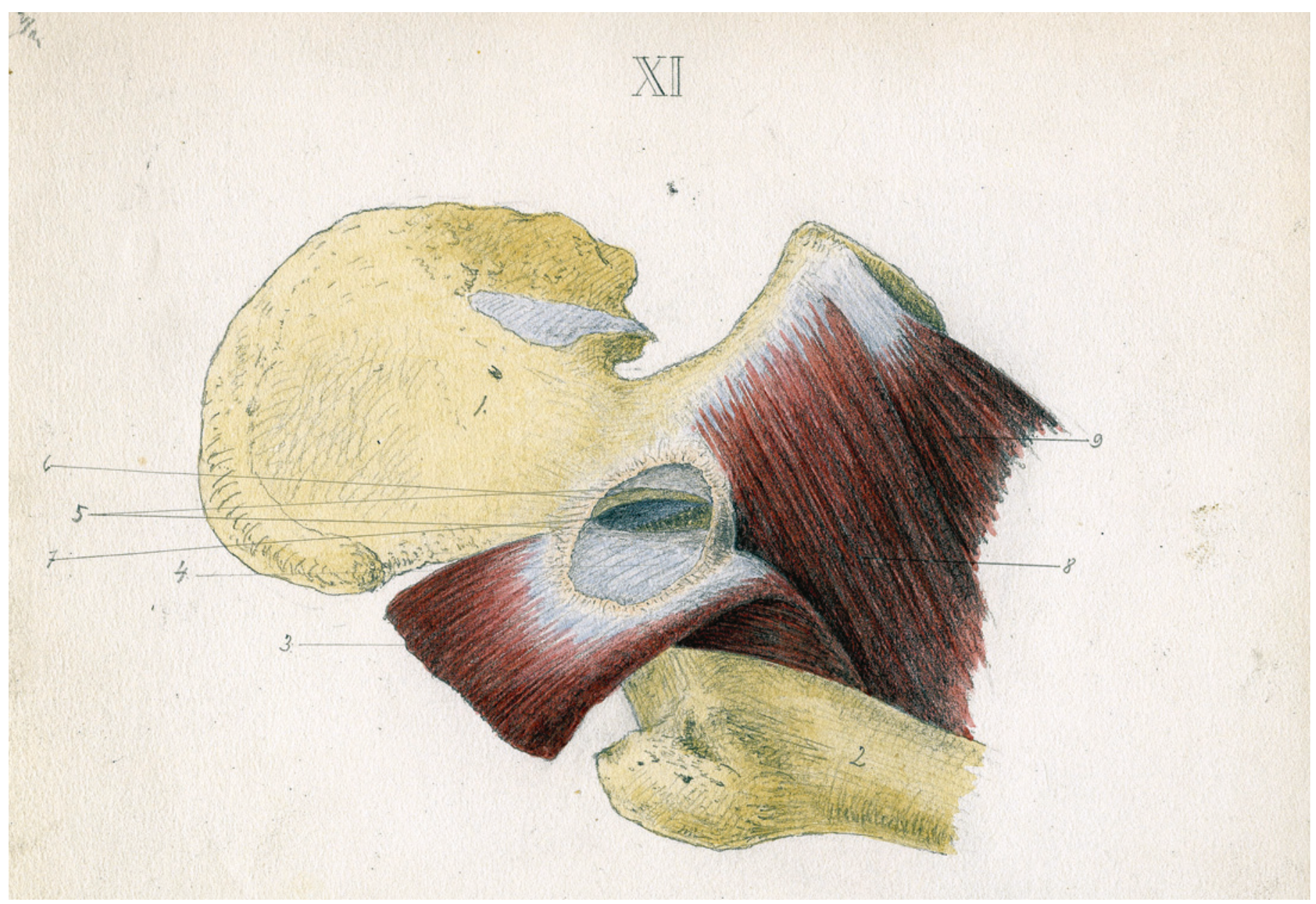




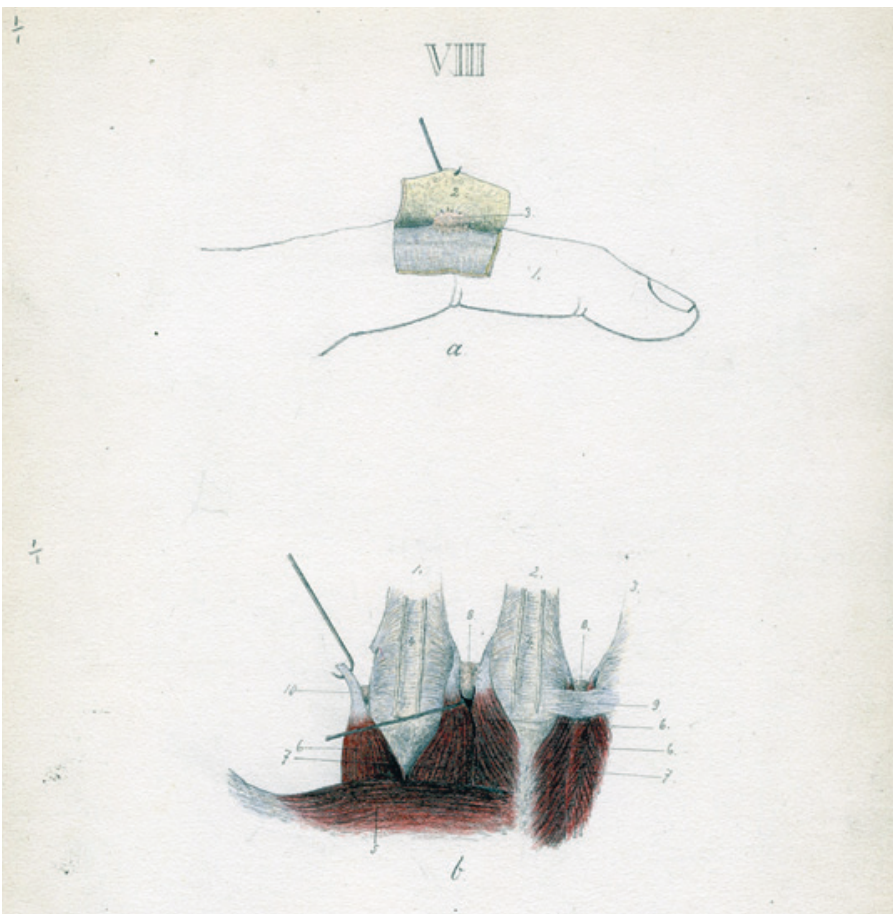

Finger og hånd. a) viser litt av pekefingerens dorsalaponevrose. b) synes å vise volarsidens vaginae synoviales med interossalmuskulatur og øvre kant av m.adductor pollicis

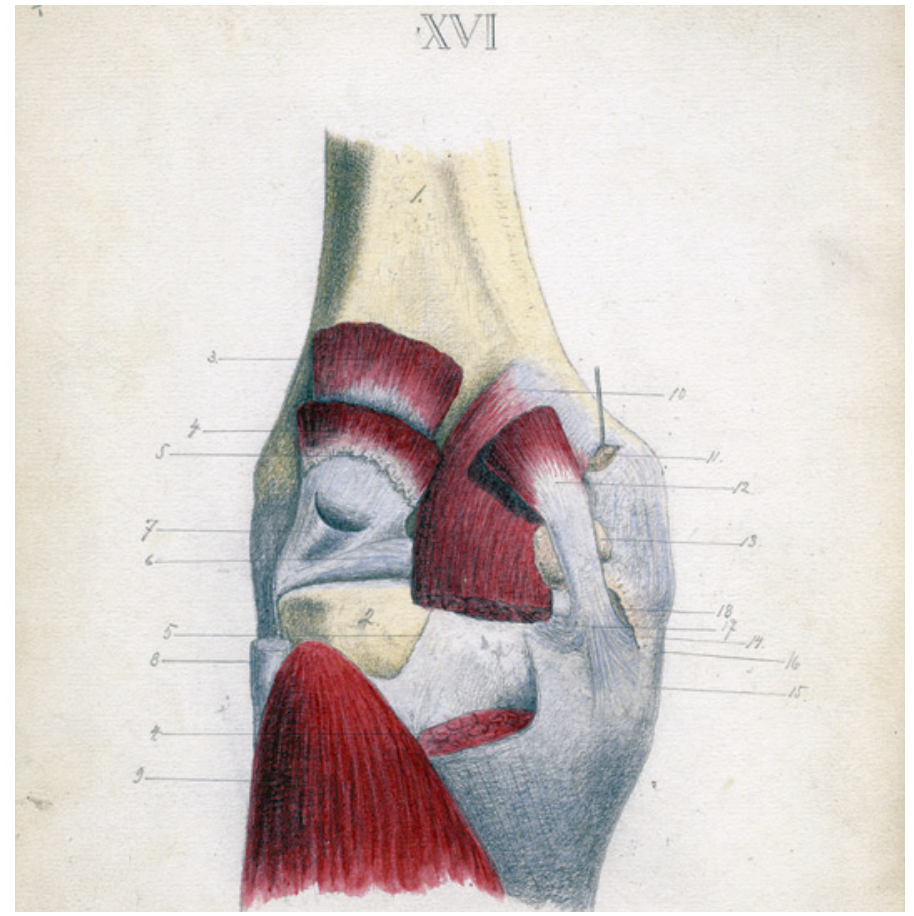

Baksiden avvenstre kneledd. Vi kjenner igjen strukturer som m. biceps femoris (8), m. soleus (9), mediale hode av m. gastrocnemius (10) og m. semimembranosus (12)

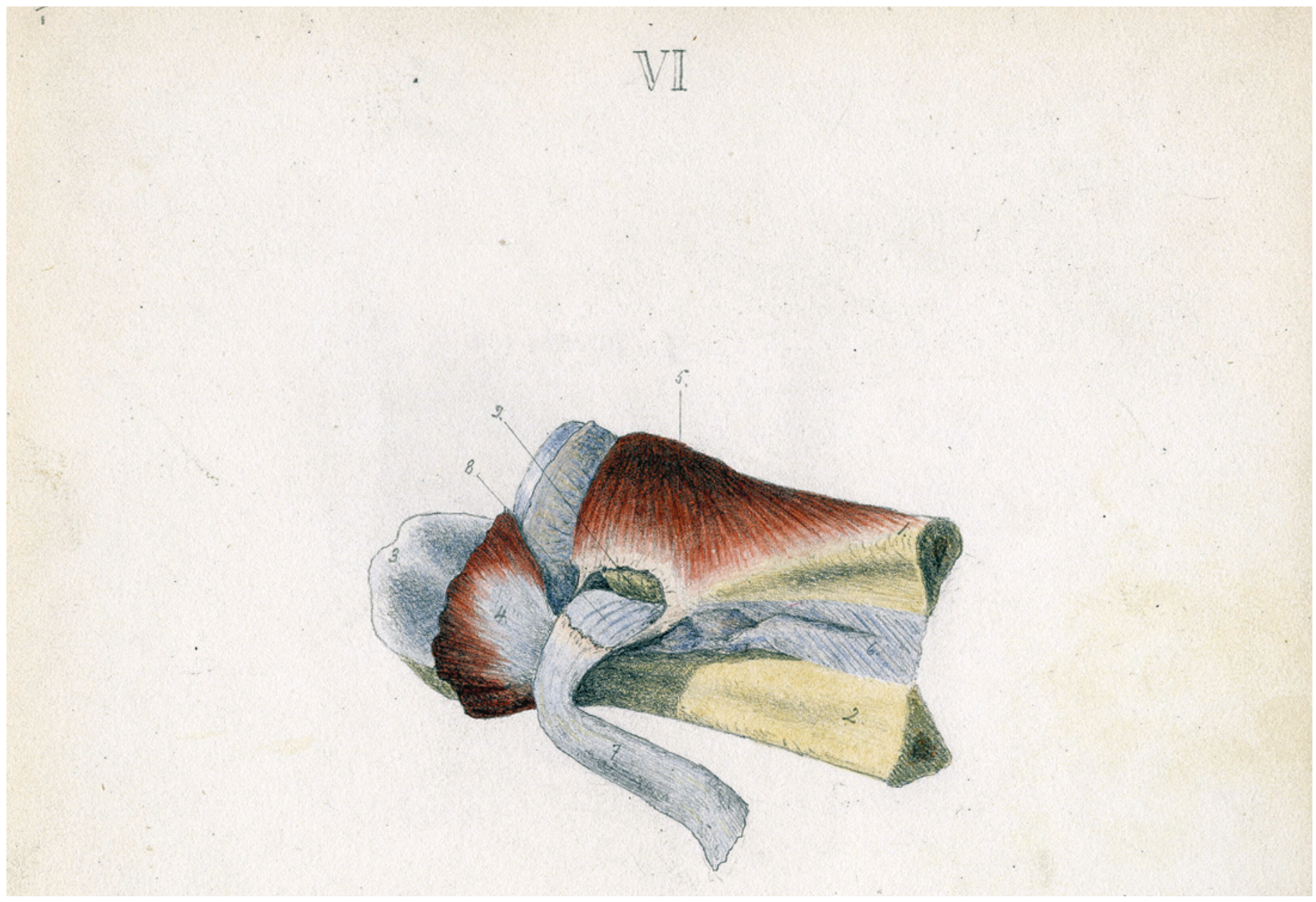


Sin kunstneriske åre hadde han vel fått gjennom faren, kunstmaler Johan Ludvig Losting (1810-76), som bl.a. er kjent for å ha illustrert Danielsen \& Boecks store lepraatlas (3). I hjemmet var det musikken som dominerte, først og fremst gjennom ekteskapet med pianistinnen Christiane Ernestine Rabe (1856-1915), som korresponderte med Edvard Grieg og holdt offentlige konserter bl.a. i samarbeid med Agathe Backer-Grøndahl (1847-1907)

Lostings tegninger er ikke daterte, og det er derfor usikkert når de kan ha blitt utført. Motivene, bl.a. med preparatene oppstilt på blokker, tyder avgjort på at det er «på anatomen» han har hatt sine forbilder. Og siden Bergen på den tid ikke hadde noe universitet, må det bety at de ble til under Lostings studietid i Kristiania - altså før 1869. Han forlot visstnok aldri Bergen som utdannet lege. Man kunne kanskje tenke seg at bildene skulle brukes som illustrasjoner til en lærebok, men noen slik var på det tidspunkt ikke påtenkt, og Gustav Adolph Guldbergs Grundtrcek af menneskets anatomi som utkom først i 1893 (4), var stort sett bare forsynt med strektegninger. Kanskje var de bare ment å være til pryd og glede for kolleger? Vakre er de iallfall.

\section{Per Holck (f. 1942)}

er professor emeritus ved Institutt for medisinske basalfag, Anatomisk avdeling, Universitetet i Oslo, med spesialkompetanse innen biologisk antropologi og rettsantropologi. Han er bestyrer av De Schreinerske Samlinger ved avdelingen.

Forfatter har fylt ut ICMJE-skjemaet og oppgir ingen interessekonflikter.

\section{Litteratur}

1. Larsen $\emptyset$, red. Norges leger. Bd. 3. Oslo: Den norske lægeforening, 1996: 632.

2. Hansen GA. Max Losting (nekrolog). Tidsskr Nor Lægeforen 1911; 31: 519.

3. Danielsen DC, Boeck CW. Om spedalskhed. Christiania: Departementet for det Indre, 1847

4. Guldberg GA. Grundtræk af menneskets anatomi. Kristiania: Jac. Dybwad, 1893. 